\title{
REVIEW
}

\section{Probiotic-based cultivation of Clarias batrachus: importance and future perspective}

\author{
Arindam Ganguly ${ }^{1}$, Amrita Banerjee ${ }^{1}$, Asish Mandal' ${ }^{2}$, Pradeep K. Das Mohapatra ${ }^{3,{ }^{*}}$ \\ ${ }^{1}$ Department of Microbiology, Vidyasagar University, Midnapore-721102, West Bengal, India. \\ 2Department of Botany, Ramananda College, Bishnupur-722122, Bankura, West Bengal, India. \\ ${ }^{3}$ Department of Microbiology, Raiganj University, Raiganj-733134, Uttar Dinajpur, West Bengal, India.
}

\begin{abstract}
Clarias batrachus (Linn.) is widely recognized in Indian sub-continent for its nutritional and economic significance. At present, it remains at a merely vulnerable state. Pathogenic infections, diminution of natural habitats and introduction of allied exotic fishes are the causes of productivity constraint, particularly in Southern Asia. Conversely, African cat fish Clarias gariepinus has been significantly identified as a potential threat to biodiversity, despite being its large scale cultivation across the world. Thus emphasis on indigenous C. batrachus farming is becoming inevitable. Currently, screening of autochthonous probiotic organisms for the cultivation of $C$. batrachus in semi-intensive manner is getting importance. At the same time, molecular omics-based technologies are also gaining considerable attention to identify potential probiotic markers. This review provides an overall concept of probiotics, its application and future perspectives in relation to the cultivation of $C$. batrachus.

Acta Biol Szeged 62(2):158-168 (2018)

\author{
KEY WORDS \\ antagonism \\ aquaculture \\ autochthonous \\ Clarias batrachus \\ probiotic
}
ARTICLE INFORMATION
Submitted
28 May 2018.
Accepted
19 August 2018
*Corresponding author
E-mail: pkdmvu@gmail.com

\section{Introduction}

Aquaculture is becoming a growing and vibrant sector to provide food security to a large population of rural mass. Southern Asia, one of the mega biodiversity hotspots, is native to many indigenous freshwater fish species. Clarias batrachus (Linn.) (Asian catfish) is one of the most soughtafter aquatic products owing to its nutritional benefits and economic significance though the production of it remains low as per the major carps are concerned. The species is presently on the verge of extinction in Southern Asia due to exploitation of its natural habitats, reclamation of wetlands, uncontrolled introduction of allied exotic fishes and infectious diseases caused by bacterial pathogens (Ahmed et al. 2012). Abrupt use of pesticides in the adjacent agriculture field also has made the situation more hostile. In aquaculture, prevention and control of aquatic diseases by chemical additives or antibiotics may generate antibiotic-resistant bacteria (ARB) and thus creates a serious concern to public health (FAO 2006). The bacterial isolates obtained from a C. batrachus population exhibited an increasing order of resistance against antibiotic colistin, ampicillin, gentamycin, carbenicillin, tetracycline, streptomycin, and ciprofloxacin (Pathak and Gopal 2005) that may pose risk to fish fauna and public health (Hoseinifar et al. 2017). Transmission of antibiotic-resistant genes may thus lead to the expansion of pathogenic populations (Bäumler and Sperandio 2016). There are many reports regarding a sharp decrease in productivity due to abrupt use of anti-microbial drugs (Alcaide et al. 2005). Probiotics are beneficial microorganisms which (as ecofriendly and biocompatible substances), are also in increased use to prevent and control aquatic diseases in recent decades. They confer protection against pathogens; e.g., by production of bacteriocins, siderophores, lysozymes and other antimicrobial compound (Ige 2013). Furthermore, they may stimulate immune responses of the host (Bandyopadhyay and Das Mohapatra 2009). Probiotics can be used as a functional feed additive to enhance feed digestibility and fecundity (Hoseinifar et al. 2017).

Scientific approaches along with social and ecological awareness need to be adapted to rescue C. batrachus from the existing deplorable state. Semi-intensive mode of cultivation must be prioritized for the conservation of native C. batrachus (ICAR-CIFA, 2016-17). Currently, use of autochthonous probiotics is gaining increased importance worldwide to cultivate the species in semiintensive manner.

\section{Aquaculture probiotics}

Probiotics are live microorganisms that confer health benefit to the host when administered in adequate amount (FAO/WHO 2001). A probiotic should be non-pathogenic 
and non-toxic to the host and must not contain any virulent or antibiotic-resistant gene (Fuller 1989). It should remain viable without genetic alteration for prolonged periods under storage and field conditions. However, competition for nutrients and production of inhibitory substances could occur even in the rearing water (Dalmin et al. 2001). The acid and bile tolerance property may enable the probiotic organisms to colonize the intestinal tract of the host (De et al. 2014). A probiotic must also exhibit high cell-surface hydrophobicity which ensures its capacity of adherence to the intestinal wall (Krasowska and Sigler 2014). It should be target specific and must reach the desired location (Wang et al. 2008).

Probiotics have been found to play a significant role in the sustainable development of aquaculture through different approaches (Table 1). Aquaculture probiotics do possess different attributes from terrestrial-based probiotics as the gastrointestinal microbiota of aquatic species is affected by the flow of water passing through the digestive tract (Gatesoupe 1999). Commercial probiotics are available both in dry and liquid forms. The dry probiotics (Table 2) consist of spore-forming microorganisms, binding material, a cascade of enzymes coupled with vitamins and other functional additives. The ingredients are then mixed with sterile water for brewing at 27-32 ${ }^{\circ} \mathrm{C}$ for 16 to $18 \mathrm{~h}$ with continuous aeration (Sahu et al. 2008). Alternatively, it can directly be added to the feed to use in the same day. However, the hatcheries mostly prefer liquid forms (Table 3) than the dry, spore-forms. Generally, commercial liquid probiotics are extremely hygroscopic and need to be kept away from moisture and sunlight. These liquid forms are applied directly to culture water in the morning and evening and have faster mode of action (Sahu et al. 2008). The immersion method of storing live fish in a probiotic-rich container for certain period of time on a regular basis is also gaining increased attention (Feliatra et al. 2018).

\section{Molecular tracking of probiotic markers}

Molecular identification technologies (e.g., proteomics, transcriptomics, secretomics, metabolomics, interactomics) are getting priority over traditional approaches in recent times to decipher the fundamental basis of probiotics functionality (Papadimitriou et al. 2015). Systematic study of functional genomics is crucial to properly validate putative probionts (Fig. 1). Several attempts have been made to identify molecular markers that would facilitate the rapid screening of probiotic strains. The probiotic must survive at high intestinal bile salt concentration through increased expression of bile stress-regulatory genes (e.g., bsh), molecular chaperones (e.g., GroES, DnaK), proteases (e.g., Clps) or DNA repair proteins (e.g., uvrB) (Papadimitriou et al. 2015; Hamon et al. 2014). Tripathy et al.
Table 1. Mode of action of aquaculture probiotics.

\begin{tabular}{ll}
\hline Mode of action & References \\
\hline $\begin{array}{l}\text { Production of inhibitory substances to the } \\
\text { pathogen }\end{array}$ & Gatesoupe 1999 \\
$\begin{array}{l}\text { Competition for adhesion sites and nutrients } \\
\text { Improvement in nutrient digestion }\end{array}$ & Fuller 1989 \\
Stimulation of innate immunity & Afrilasari et al. 2017 \\
Elevates phagocytic activity & Kim and Austin 2006 \\
Growth promotion & Butprom et al. 2013 \\
Influence on water quality & Falaye et al. 2016 \\
Stress tolerance & Crab et al. 2010 \\
Interference in quorum sensing & Fuller 1989 \\
Antifungal activity & Defoirdt et al. 2004 \\
Antiviral activity & De et al. 2014 \\
Protection against infection & Sahu et al. 2008 \\
Production of extracellular enzymes & Gram et al. 1999 \\
Production of vitamins & Irianto and Austin 2002 \\
Production of siderophores & Balcazar et al. 2006 \\
Improvement of host reproduction rate & De et al. 2014 \\
Improvement of haematological profile & Ghosh et al. 2004 \\
Bioremediation & Ayoola et al. 2013 \\
\hline
\end{tabular}

(2014) observed several probiotic marker genes including fibronectin binding protein $(f b p)$, mucus binding protein $(\mathrm{mbp})$ and bile salt hydrolase (bsh) in Lactobacillus plantarum KSBT56 strain. The fatty acid biosynthesis (e.g., fab gene) or quorum sensing (e.g., luxS gene) of bacterial strain must be associated with the tolerance to acidic environment (Defoirdt et al. 2004; Hamon et al. 2014). Adhesion is the process of reversible accumulation of bacterial cells belonging to autoaggregation or coaggregation. Probiotics must encode aggregation promoting factor (e.g., Apf), FbpA protein or adh gene to colonize and exert antimicrobial (e.g., albE) and immune-modulatory (e.g., slpA) substances (Papadimitriou et al. 2015). Bacillus licheniformis, Bacillus mycoides, Bacillus cereus, Bacillus thuringiensis, Bacillus amyloliquefaciens, Bacillus endophyticus, Bacillus halodurans, Bacillus paralicheniformis and Bacillus methylotrophicus contain class II lanthipeptide that can be identified by the expression of lanM gene (Zhao and Kuipers 2016). The genome mining study revealed expression of sublancin 168 and other putative gene clusters of glycocins in $B$. thuringiensis, B. cereus, Bacillus weihenstephanensis, Bacillus lehensis, Bacillus sp., Geobacillus sp. and Paenibacillus sp. (Zhao and Kuipers 2016). B. thuringiensis, B. cereus and Bacillus sp. BH072 were reported to contain gene clusters of transmembrane protein colicins that depolarize the cytoplasm membrane of pathogen leading to dissipation of 
Table 2. Feed probiotics used in aquaculture.

\begin{tabular}{|c|c|c|c|}
\hline Host & Probiotic & Effect on host & References \\
\hline $\begin{array}{l}\text { Dicentrarchus labrax } \\
\text { (European sea bass) }\end{array}$ & $\begin{array}{l}\text { Debaryomyces hansenii, Saccharomyces } \\
\text { cerevisiae }\end{array}$ & Enhanced growth performance and feed efficiency & Tovar et al. 2002 \\
\hline $\begin{array}{l}\text { Epinephelus coioides } \\
\text { (Grouper) }\end{array}$ & $\begin{array}{l}\text { Bacillus pumilus SE5 and Bacillus clausii } \\
\text { DE5 }\end{array}$ & $\begin{array}{l}\text { Improved growth performance and immune } \\
\text { responses }\end{array}$ & Sun et al. 2010 \\
\hline $\begin{array}{l}\text { Ictalurus punctatus } \\
\text { (Channel catfish) }\end{array}$ & Bacillus strain & Prevented enteric septicaemia of catfish (ESC) & Ran et al. 2012 \\
\hline $\begin{array}{l}\text { Labeo rohita } \\
\text { (Rohu) }\end{array}$ & Bacillus circulans & Improved growth performance and feed efficiency & Ghosh et al. 2004 \\
\hline $\begin{array}{l}\text { Macrobrachium rosenbergii } \\
\text { (Prawn) }\end{array}$ & Bacillus subtilis & $\begin{array}{l}\text { Enhanced growth and survivability against patho- } \\
\text { genic Aeromonas hydrophila }\end{array}$ & $\begin{array}{l}\text { Keysami and } \\
\text { Mohammadpour } 2013\end{array}$ \\
\hline $\begin{array}{l}\text { Oncorhynchus mykiss } \\
\text { (Rainbow trout) }\end{array}$ & Lactobacillus rhamnosus JCM 1136 & Stimulated immune response & Panigrahi et al. 2005 \\
\hline $\begin{array}{l}\text { Oncorhynchus mykiss } \\
\text { (Rainbow trout) }\end{array}$ & $\begin{array}{l}\text { Carnobacterium maltaromaticum B26, } \\
\text { Carnobacterium divergens B33 }\end{array}$ & $\begin{array}{l}\text { Enhanced the cellular and humoral immune } \\
\text { responses }\end{array}$ & Kim and Austin 2006 \\
\hline $\begin{array}{l}\text { Oncorhynchus mykiss } \\
\text { (Rainbow trout) }\end{array}$ & Bacillus subtilis AB1 & Controlled Aeromonas infection & Newaj-Fyzul et al. 2007 \\
\hline $\begin{array}{l}\text { Oncorhynchus mykiss } \\
\text { (Rainbow trout) }\end{array}$ & $\begin{array}{l}\text { Aeromonas hydrophila, Vibrio fluvialis, } \\
\text { Carnobacterium sp. }\end{array}$ & Enhanced growth performance and feed efficiency & Irianto and Austin 2002 \\
\hline $\begin{array}{l}\text { Oncorhynchus mykiss } \\
\text { (Rainbow trout) }\end{array}$ & Lactobacillus rhamnosus (ATCC 53103) & Stimulated immune responses & Nikoskelainen et al. 2003 \\
\hline $\begin{array}{l}\text { Oreochromis niloticus } \\
\text { (Nile tilapia) }\end{array}$ & $\begin{array}{l}\text { Bacillus subtilis (ATCC 6633), Lactobacil- } \\
\text { lus acidophilus }\end{array}$ & $\begin{array}{l}\text { Stimulated the gut immune system; enhanced the } \\
\text { immune and health status; increased the survival } \\
\text { rate and body-weight gain }\end{array}$ & Aly et al. 2008 \\
\hline $\begin{array}{l}\text { Oreochromis niloticus } \\
\text { (Nile tilapia) }\end{array}$ & $\begin{array}{l}\text { Streptococcus faecium, Lactobacillus } \\
\text { acidophilus, Saccharomyces cerevisiae }\end{array}$ & $\begin{array}{l}\text { Increased growth, digestibility and feed conversion } \\
\text { ratio }\end{array}$ & Lara-Flores et al. 2003 \\
\hline $\begin{array}{l}\text { Penaeus monodon } \\
\text { (Asian tiger shrimp) }\end{array}$ & Bacillus sp. S11 & Enhanced growth performance and feed efficiency & Rengpipat et al. 1998 \\
\hline $\begin{array}{l}\text { Salmo salar } \\
\text { (Atlantic salmon) }\end{array}$ & Carnobacterium divergens 6251 & $\begin{array}{l}\text { Inhibited Aeromonas salmonicida and Vibrio } \\
\text { anguillarum-induced pathogenicity }\end{array}$ & Ringo et al. 2007 \\
\hline $\begin{array}{l}\text { Salmo salar } \\
\text { (Atlantic salmon) }\end{array}$ & Carnobacterium sp. & $\begin{array}{l}\text { Inhibited Aeromonas salmonicida, Vibrio ordalii, } \\
\text { Yersinia ruckeri and reduced disease outbreak }\end{array}$ & Robertson et al. 2000 \\
\hline
\end{tabular}

cellular energy (Zhao and Kuipers 2016). Probiotic often contain genes (e.g., tas A, tapA, bslA) to synthesize biofilms by secreting extracellular matrix protein. Bacillus subtilis biofilms is synthesized by the products of the eps gene ( $\mathrm{Pa}-$ padimitriou et al. 2015). Several gene or protein markers were involved in biofilm formation (e.g., bslA and tapA), quorum-sensing (e.g., $P l c R)$ in B. cereus and B. thuringiensis (Majed et al. 2016). sipW, tas A, and calY transcriptions were repressed by the SinR regulator which controls biofilm formation through production of kurstakin; a lipopeptide biosurfactant (Majed et al. 2016). The further identification of molecular markers including housekeeping genes can enrich our understanding about the probable mode of action of probiotics.

\section{The Asian catfish Clarias batrachus}

Asian catfish C. batrachus has a broad depressed head covered with bony plates, the snout of which contains four pairs of sensory barbels (Jayaram 1981). The skin mucus often contains bactericidal proteins and provides protection against invading pathogens (Elavarasi et al.
2013). The body, generally grayish-black, is cylindrical and tapers towards the caudal peduncle. C. batrachus typically attains a standard length of $225-300 \mathrm{~mm}$. However, in India it is found to be around $183.1 \mathrm{~mm}$ in length as an average ( $\mathrm{Ng}$ and Kottelat 2008).

The nutritional profile of C. batrachus contains easily digestible high-grade protein (16.26 g/100 g), iron (2.20 $\mathrm{mg} / 100 \mathrm{~g}$ ), minerals, good cholesterol and polyunsaturated fatty acids (ICAR-CIFA). It is also a rich source of vitamin $\mathrm{A}(6.03 \mathrm{IU} / 100 \mathrm{~g})$, vitamin $\mathrm{D}(44.73 \mathrm{IU} / 100 \mathrm{~g})$ and essential amino acids (ICAR-CIFA; Mohanty et al. 2014).

C. batrachus can be found in both fresh and brackish water of Sri Lanka, India, Pakistan, Bangladesh, China, Burma, Malaya, Singapore, Philippines, Borneo, Java, and Thailand (Talwar and Jhingran 1991). They can be found in a variety of habitats, most commonly in muddy or swampy low-land field and rice fields. The major constraint in the cultivation of $C$. batrachus in natural resources is the non-availability of quality seeds. The scarcity of seeds arises from various factors like: indiscriminate use of pesticides in paddy fields, industrial effluents, diminution 


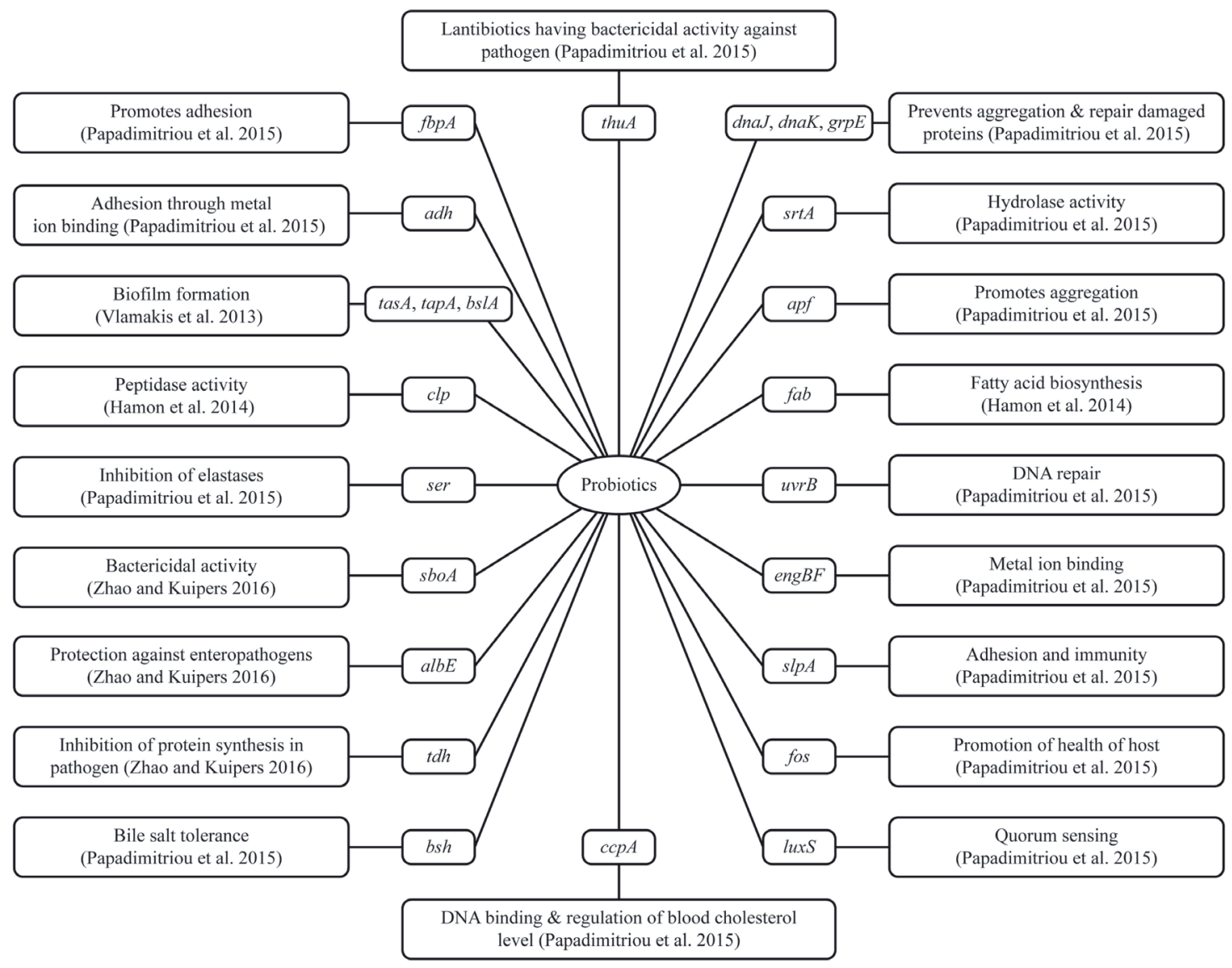

Figure 1. Genes related to potential probiotic properties.

of breeding area due to siltation, intermittent periods of drought and illicit fishing of juveniles and brood fishes (Dhara and Saha 2013). The exotic catfish C. gariepinus that has morphological resemblance to indigenous $C$. batrachus is frequently misled by some dishonest traders (Khedkar et al. 2015). These have threatened the mere existence of this indigenous catfish. Therefore, it becomes crucial to carry out breeding and rearing of C. batrachus to meet the need of the society. As the species is sold only in living condition and cannot be transported over long distances, a culturing in semi-intensive manner becomes necessary. Thus, cultivation in small production pond and its supply to the market in living condition would be a better practice for catfish farming.

\section{Probiotics in Clarias species}

The invasive alien catfish C. gariepinus has presently been considered as a potential threat due to its frenzied feeding behavior and hence, farming of indigenous C. batrachus is regaining its importance (Radhakrishnan et al. 2011). However, reports on the use of probiotics in C. gariepinus are available, but our knowledge is still limited so far as C. batrachus (Table 4) are concerned. In this regard, a protocol to screen putative probiotic strain for cultivation of C. batrachus can be proposed (Fig. 2).

Probiotic strains usually synthesize extracellular enzymes (e.g., proteases, amylases, lipases) and growth factors (e.g., vitamins, fatty acids, amino acids) which can stimulate the appetite and endorse fish nutrition by the detoxification of toxic substances and breakdown of indigestible components (Irianto and Austin 2002; Balcazar et al. 2006). Consequently, nutrients are more readily absorbed when the feed is supplemented with probiotics (Afrilasari et al. 2017). The use of Lactobacillus acidophilus with a diet for 12 weeks has exhibited improved specific growth rate (SGR), relative growth rate (RGR), protein efficiency ratio (PER), feed conversion ratio (FCR), haematological parameter and significantly $(\mathrm{p}<0.05)$ higher survival rate (SR) in C. gariepinus fingerlings (Ige 2013). Banerjee and co-workers (2015) isolated an extracellular enzyme-producing bacterial strain Bacillus licheniformis from C. batrachus. Dey et al. (2016) obtained an extracellular enzyme-producing autochthonous gut bacteria $B$. cereus HG01 (KR809412) from C. batrachus. Ayo Olalusi et 
Table 3. Examples of water probiotics used in aquaculture.

\begin{tabular}{|c|c|c|c|}
\hline Host & Probiotic & Effect on host & References \\
\hline $\begin{array}{l}\text { Litopenaeus vannamei } \\
\text { (Pacific white shrimp) }\end{array}$ & Bacillus sp. and Lactobacillus & $\begin{array}{l}\text { Improved the environmental quality of the sediment } \\
\text { and water in ponds with closed recirculation systems }\end{array}$ & Paiva-Maia et al. 2013 \\
\hline $\begin{array}{l}\text { Oncorhynchus mykiss } \\
\text { (Rainbow trout) }\end{array}$ & Pseudomonas fluorescens AH2 & $\begin{array}{l}\text { Increased survival rate against pathogenic } \\
\text { Vibrio anguillarum }\end{array}$ & Gram et al. 1999 \\
\hline $\begin{array}{l}\text { Penaeus monodon } \\
\text { (Asian tiger shrimp) }\end{array}$ & Bacillus sp. & $\begin{array}{l}\text { Improved growth and survival rate, maintained water } \\
\text { quality }\end{array}$ & Dalmin et al. 2001 \\
\hline $\begin{array}{l}\text { Penaeus monodon } \\
\text { (Asian tiger shrimp) }\end{array}$ & $\begin{array}{l}\text { Bacillus pumilus, B. licheniformis } \\
\text { and } B \text {. subtilis }\end{array}$ & $\begin{array}{l}\text { Reduced total ammonia nitrogen (TAN); improved growth } \\
\text { and survival rate }\end{array}$ & Devaraja et al. 2013 \\
\hline $\begin{array}{l}\text { Penaeus vannamei } \\
\text { (White shrimp) }\end{array}$ & $\begin{array}{l}\text { Bacillus sp., S. cerevisiae, } \\
\text { Nitrosomonas sp. }\end{array}$ & $\begin{array}{l}\text { Reduced concentrations of nitrogen and phosphorus, } \\
\text { increased yields of shrimp }\end{array}$ & Wang et al. 2005 \\
\hline $\begin{array}{l}\text { Scophthalmus maximus } \\
\text { (Turbot larva) }\end{array}$ & Lactic acid bacteria & Increased survival rate against vibriosis & Gatesoupe 1994 \\
\hline $\begin{array}{l}\text { Scophthalmus maximus } \\
\text { (Turbot larvae) }\end{array}$ & Roseobacter sp. & Improved survival rate & Hjelm et al. 2004 \\
\hline
\end{tabular}

al. (2014) showed that viable feed-probiotics administered to C. gariepinus increased the hematological parameter and digestive enzyme (amylase and lipase) activity of the catfish within acceptable range. Probiotic L. plantarum infused diet considerably enhanced hematological parameters, carcass protein and mineral composition of African catfish C. gariepinus (Nwanna and Tope-Jegede 2016).

A higher level of immunity was also noted while challenging with pathogenic Salmonella typhi than those with non-probiotic diet. Probiotic Bacillus aryabhattai KP784311, B. flexus KR809411, B. cereus KR809412 encapsulated chironomid midge larvae significantly $(\mathrm{p}<$ 0.05 ) increased specific growth rate and survivability of C. batrachus (Dey et al. 2017).

Synergistic relationships among different bacterial strains may be more effective and consistent than a single strain of probiotic (Salinas et al. 2008). L. plantarum and Pseudomonas fluorescens have a synergistic effect on each other and therefore produced higher specific growth rate and survival rate in C. gariepinus fingerlings than the control diet (Omenwa et al. 2015). Ayoola et al. (2013) reported that administering a mixture of Lactobacillus and Bifidobacterium species in a feeding trial (90 days) enhanced feed efficiency, growth rate, survivability and nutritional quality of $C$. gariepinus juveniles. The hydrobiological parameters are also important in maintaining the integrity of aquatic ecosystem and have direct influence on the productivity of C. batrachus (Ganguly et al. 2017).

Biofloc technology is a sustainable method to meliorate water quality and feed utilization efficiency of aquatic animals (Crab et al. 2010). The fermented bioflocs inoculated with the bacterium $B$. cereus enhanced the growth and feed utilization efficiency of juvenile catfish C. gariepinus (Hapsari 2016). Putra et al. (2017) also reported to achieve better growth performance and feed utilization efficiency in African catfish C. gariepinus using biofloc technology infused with the Bacillus probiotic.

Probiotic microorganisms often exert bactericidal or bacteriostatic substances to restrict the propagation of pathogenic bacteria (Sahu et al. 2008). Kato et al. (2016) have conducted a study to isolate and identify probiotic bacteria from the surface of the African catfish C. gariepinus. Among all the isolates, Lactococcus sp. and Lactobacillus $s p$. have shown potential antimicrobial activity against selected pathogenic strains. Lactobacillus fermentum LbFF4 and L. plantarum LbOGI isolated from C. gariepinus showed in vitro antibacterial activities against gram negative bacteria Citrobacter, E. coli, Klebsiella, Proteus, Pseudomonas and Salmonella (Ogunshe and Olabode 2009). Fortified diet enriched with $L$. plantarum enhanced growth, weight gain and FCR of cultured C. gariepinus fingerlings (Falaye et al. 2016). A parallel study with C. gariepinus showed increased growth performance, FCR, PER, protein productive value and energy retention when the fish feed was supplemented with a commercial probiotic strain of Bacillus (El-Haroun 2007). The organism germinated in the intestine and synthesized digestive enzymes amylase, protease and lipase which in turn contributed improved feed efficiency.

Probiotics often exert immunomodulating substances to stimulate immune response against pathogenic invasion (De et al. 2014). Vibrio anguillarum, Vibrio alginolyticus and Aeromonas hydrophila were reported to cause pathogenicity in C. batrachus (Ahmed et al. 2012). Dahiya et al. (2012) successfully experimented with C. batrachus fingerlings, treating them with probiotics that resulted remarkable increase of immunity and hemoglobin level of the catfish. L. plantarum $\mathrm{C} 014$ infused $\left(10^{7} \mathrm{cfu} / \mathrm{g}\right)$ diet improved innate immune response and disease resistance ability of hybrid catfish. The probiotic-supplemented diet elevated 


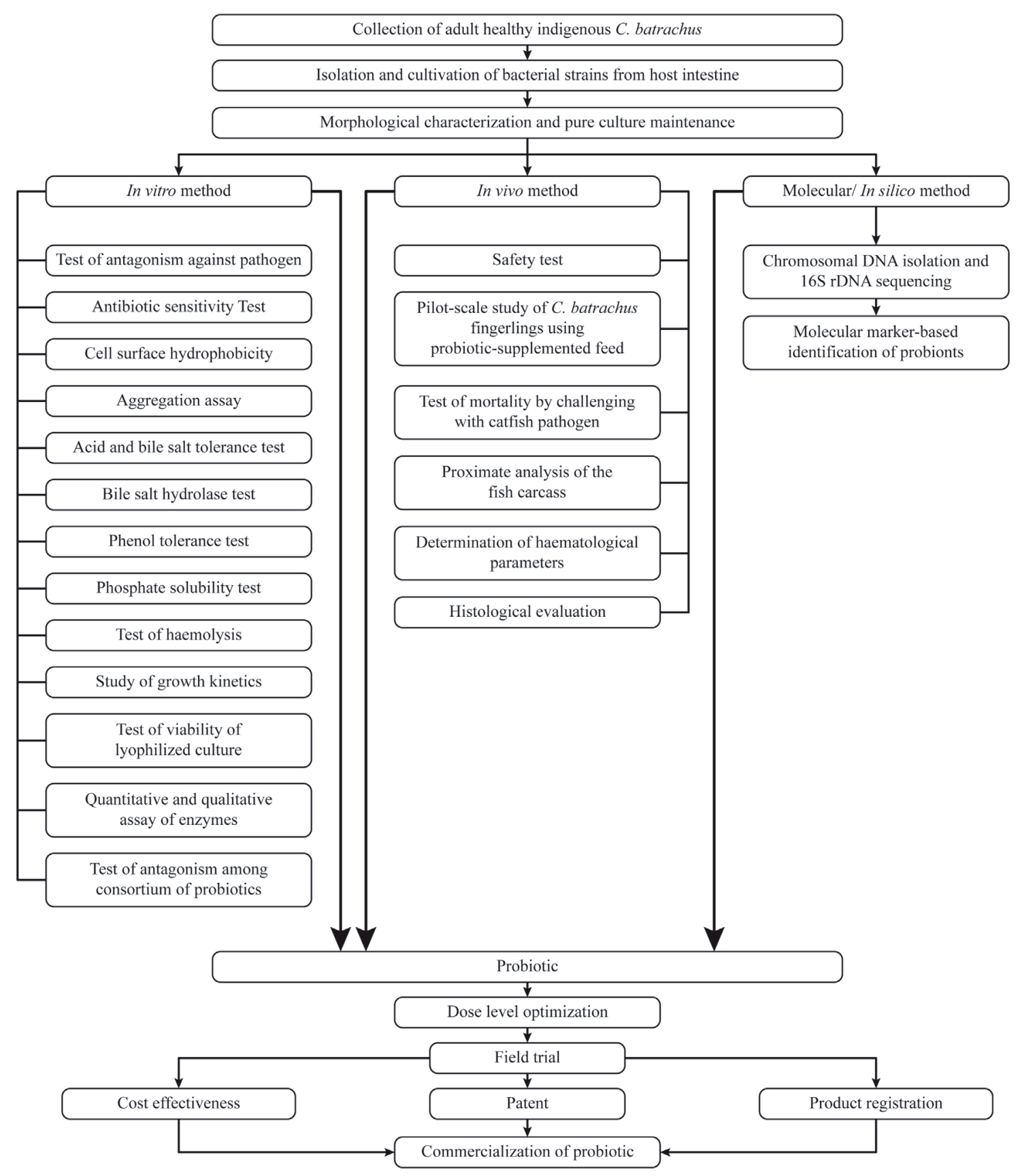

Figure 2. Diagram for screening of autochthonous probiotic strain for the cultivation of $C$. batrachus.

phagocytic activity, lysozyme efficacy and survival rate of hybrid catfish against $A$. hydrophila infection (Butprom et al. 2013).

Probiotic microorganisms resist the establishment of pathogen by adsorbing and colonizing the digestive tract of the host (Fuller 1989) through a process called competitive exclusion. One experiment was carried out to evaluate the effects of the probiotic bacterium Bacillus megaterium PTB 1.4 on the growth performance, intestinal microflora and digestive enzyme activity of Clarias sp. (Afrilasari et al. 2017). The results showed significantly higher ( $\mathrm{p}<$ $0.05)$ SGR and increased activity of protease and amylase in fish maintained on the probiotic-supplemented diet compared to those on the control diet. Bairagi et al. (2002) isolated distinct microbial source of digestive enzymes amylase, lipase and protease from the gastrointestinal tract of C. batrachus that may contribute towards better feed formulations. Yakubu et al. (2016) assessed the effects 
of commercial probiotic (Biogut) on C. gariepinus and observed improved growth and survival rate of the fry. Jahan et al. (2016) noticed better growth performance, SGR and proximate carcass compositions of C. batrachus fingerlings fed with probiotic-supplement diet compared to the control diet.

Quorum sensing is a bacterial cell-to-cell communication mechanism leading to the alternation of gene expression in response to high population density (De Almeida et al. 2016). The quorum quenching or disruption of quorum sensing is considered as potential antiinfective strategy in aquaculture (Defoirdt et al. 2004). The probiotic Lysinibacillus sphaericus, B. amyloliquefaciens and $B$. cereus have been reported to disintegrate acyl homoserine lactone (AHL), the quorum sensing molecule of pathogenic A. hydrophila by producing AHL-lactonase and thus preventing motile aeromonad septicemia (MAS) in C. gariepinus (Novita et al. 2015).

\section{Conclusion}

In the era of global food crisis, aquaculture stands as a sustainable approach to restore biodiversity and ensure nutritional security (Naylor et al. 2000). Countries where a large section is battling with protein deficiency and malnutrition, consumption of C. batrachus may hold promising potentiality in uplifting the overall health status of the populace. To reinstate the genetic resources of C. batrachus, semi-intensive aquaculture practices has to be adopted. A concerted effort is the need of the hour to cultivate C. batrachus due to its apparent nutritional and economic significance, whereas rational selection and proper validation of probiotic is a cause of concern. The limnological properties of aquatic pond may pose a threat to the establishment of probiotics and thus affect fish health. The laboratory result with test probiotics should be in accordance with large-scale commercial implication. The preservation of probiotics maintaining the viability of the organisms is yet to be standardized. The dose-level optimization of a certain probiotic strain also needs to be carried out before commercialization.

However, different molecular technique-based approaches (polymerase chain reaction, multiplex-PCR, pulsed field gel electrophoresis, random amplified polymorphic DNA, fourier-transform infrared spectroscopy, denaturing gradient gel electrophoresis, temporal temperature gradient gel electrophoresis, fluorescence in situ hybridization) are now being increasingly used for the analysis of GI microflora to screen autochthonous

Table 4. Application of probiotics in Clarias species.

\begin{tabular}{|c|c|c|c|}
\hline Host & Probiotic & Effect on host & References \\
\hline $\begin{array}{l}\text { Clarias batrachus } \\
\text { (Asian catfish) }\end{array}$ & Lysinibacillus sphaericus & Inhibited Vibrio harveyi infection & Ganguly et al. 2018 \\
\hline $\begin{array}{l}\text { Clarias batrachus } \\
\text { (Asian catfish) }\end{array}$ & Lactobacillus sporogenes, Saccharomyces boulardii & Controlled A. hydrophila infection & Dahiya et al. 2012 \\
\hline $\begin{array}{l}\text { Clarias batrachus } \\
\text { (Asian catfish) }\end{array}$ & $\begin{array}{l}\text { Nitromonas, Rhodococcus, Bacillus megaterium, Lech- } \\
\text { eni formis, Desulphovibrio sulphuricum, Pseudomonas, } \\
\text { Chromatium, Chlorobium, Thiobacillus thioxidants, } \\
\text { Thiobacillus ferroxidant, Methylomonas metyhanica, } \\
\text { Glucon acetobactor, Azospirillum, Trichoderma, Shizo- } \\
\text { phyllum commune, Sclertium gluconicum }\end{array}$ & $\begin{array}{l}\text { Increased haematological profile, inhibited } A \text {. } \\
\text { hydrophila infection }\end{array}$ & Dahiya et al. 2012 \\
\hline $\begin{array}{l}\text { Clarias gariepinus } \\
\text { (African catfish) }\end{array}$ & Lactobacillus acidophilus & Improved growth, survivability, feed efficiency & Al-Dohail et al. 2009 \\
\hline $\begin{array}{l}\text { Clarias gariepinus } \\
\text { (African catfish) }\end{array}$ & Lactobacillus acidophilus & $\begin{array}{l}\text { Enhanced haematology parameters, stimulat- } \\
\text { ed immunity, inhibited Staphylococcus xylosus, } \\
\text { Aeromonas hydrophila gr.2 and Streptococcus } \\
\text { agalactiae infection }\end{array}$ & Al-Dohail et al. 2011 \\
\hline $\begin{array}{l}\text { Clarias gariepinus } \\
\text { (African catfish) }\end{array}$ & Bacillus thuringiensis & $\begin{array}{l}\text { Enhanced of cellular non-specific immune } \\
\text { response against } A \text {. hydrophila infection }\end{array}$ & Reneshwary et al. 2011 \\
\hline $\begin{array}{l}\text { Clarias gariepinus } \\
\text { (African catfish) }\end{array}$ & Lactobacillus acidophilus & $\begin{array}{l}\text { Improved fish health, enhanced haematologi- } \\
\text { cal parameters }\end{array}$ & Olayinka and Afolabi 2013 \\
\hline $\begin{array}{l}\text { Clarias gariepinus } \\
\text { hybrid (MCF }{ }^{\circ} \times \\
\text { QCF }^{\lambda} \text { ) (Egyptian } \\
\text { African catfish) }\end{array}$ & Saccharomyces cerevisiae & Increased body weight and growth rate & Essa et al. 2011 \\
\hline $\begin{array}{l}\text { Clarias gariepinus } \\
\text { (African catfish) }\end{array}$ & $\begin{array}{l}\text { Lactobacillus acidophilus, Bacillus subtilis, Lactobacil- } \\
\text { lus bulgaricus }\end{array}$ & $\begin{array}{l}\text { Enhanced growth and survival rate of African } \\
\text { catfish larva }\end{array}$ & Dennis and Uchenna 2016 \\
\hline $\begin{array}{l}\text { Clarias orientalis } \\
\text { (Catfish) }\end{array}$ & Lactobacillus sp. & $\begin{array}{l}\text { Increased growth and survival rate, inhibited } \\
\text { Aeromonas and Vibrio sp. }\end{array}$ & Dhanasekaran et al. 2008 \\
\hline
\end{tabular}


probiotics (Kim et al. 2007). The 'omics' studies may also provide a potential opportunity to obtain probiotic microorganisms avoiding traditional cultivation methods. The use of probiotics to potentiate the benefits of C. batrachus stand necessary and its application is both empirical and scientific. A futuristic approach with probiotics maintaining ecologically sound management practices has to be adopted to bring about socio-economic upliftment in Asian countries which are the native place of C. batrachus.

\section{Acknowledgement}

The authors are thankful to Prof. Saptarshi Roy, Department of English; B.S. College for his valuable suggestions regarding the polishing of English language.

\section{References}

Afrilasari W, Widanarni W, Meryandini A (2017) Effect of probiotic Bacillus megaterium PTB 1.4 on the population of intestinal microflora, digestive enzyme activity and the growth of catfish (Clarias sp.). Hayati J Biosci 24:1-5.

Ahmed R, Pandey RB, Arif SH, Nabi N, Jabeen M, Hasnain A (2012) Polymorphic $\beta$ and $\gamma$ lens crystalline demonstrate latitudinal distribution of threatened walking catfish Clarias batrachus (Linn.) populations in North-Western India. J Biol Sci 12:98-104.

Alcaide E, Blasco MD, Esteve C (2005) Occurrence of drug-resistant bacteria in two European eel farms. Appl Environ Microbiol 71(6):3348-3350.

Al-Dohail MA, Hasim R, Aliyu-Paiko M (2009) Effects of the probiotic, Lactobacillus acidophilus, on the growth performance, haematology parameters and immunoglobulin concentration in African Catfish (Clarias gariepinus, Burchell 1822) fingerling. Aquac Res 40(14):1642-1652.

Al-Dohail MA, Hasim R, Aliyu-Paiko M (2011) Evaluating the use of Lactobacillus acidophilus as a biocontrol agent against common pathogenic bacteria and the effects on the haematology parameters and histopathology in African catfish Clarias gariepinus juveniles. Aquac Res 42(2):196-209.

Aly SM, Ahmed YAG, Ghareeb AAA, Mohamed MF (2008) Studies on Bacillus subtilis and Lactobacillus acidophilus, as potential probiotics, on the immune response and resistance of Tilapia nilotica (Oreochromis niloticus) to challenge infections. Fish Shellfish Immunol 25(1-2):128-136. Ayo Olalusi CI, Mojekwu T, Adeleke TA, Bernard E, Adejonwo MO, Adeyemi YB (2014) Digestive enzymes assay and haematological profile of Clarias gariepinus juveniles fed with probiotics supplemented diets. Adv Plants Agric Res 1(4):1-5.
Ayoola SO, Ajani EK, Fashae OF (2013) Effect of probiotics (Lactobacillus and Bifidobacterium) on growth performance and hematological profile of Clarias gariepinus juveniles. World J Fish Mar Sci 5(1):01-08.

Bairagi A, Ghosh KS, Sen SK, Ray AK (2002) Enzyme producing bacterial flora isolated from fish digestive tracts. Aquacult Int 10:109-121.

Balcazar JL, Blas ID, Ruiz-Zarzuela I, Cunningham D, Vendrell D, M' uzquiz JL (2006) The role of probiotics in aquaculture. Vet Microbiol 114(3-4):173-186.

Bandyopadhyay P, Das Mohapatra PK (2009) Effect of probiotic bacterium Bacillus circulans PB7 in the formulated diets: on growth, nutritional quality and immunity of Catla catla (Ham.). Fish Physiol Biochem 35:467-478.

Banerjee G, Dan SK, Nandi A, Ghosh P, Ray AK (2015) Autochthonous gut bacteria in two Indian air-breathing fish, climbing perch (Anabas testudineus) and walking catfish (Clarias batrachus): mode of association, identification and enzyme producing ability. Pol J Microbiol 64(4):361-368.

Bäumler AJ, Sperandio V (2016) Interactions between the microbiota and pathogenic bacteria in the gut. Nature 535:85-93.

Butprom S, Phumkhachorn P, Rattanachaikunsopon P (2013) Effect of Lactobacillus plantarum C014 on innate immune response and disease resistance against Aeromonas hydrophila in hybrid catfish. Scientific World J 2013:1-6.

Crab R, Chielens B, Wille M, Bossier P, Verstraete W (2010) The effect of different carbon sources on the nutritional value of bioflocs, a feed for Macrobrachium rosenbergii post larvae. Aquac Res 41(4):559-567.

Dahiya T, Sihag RC, Gahlawat SK (2012) Effect of probiotics on the haematological parameters of Indian magur (Clarias batrachus L.). J Fish Aquat Sci 7(4):279-290.

Dalmin G, Kathiresan K, Purushothaman A (2001) Effect of probiotics on bacterial population and health status of shrimp in culture pond ecosystem. Indian J Exp Biol 39:939-942.

De Almeida FA, Pinto UM, Dantas Vanetti MC (2016) Novel insights from molecular docking of SdiA from Salmonella enteritidis and Escherichia coli with quorum sensing and quorum quenching molecules. Microb Pathog 99:178-190.

De BC, Meena DK, Behera BK, Das P, Das Mohapatra PK, Sharma AP (2014) Probiotics in fish and shellfish culture: immunomodulatory and ecophysiological responses. Fish Physiol Biochem 40(3):921-971.

Defoirdt T, Boon N, Bossier P, Verstraete W (2004) Disruption of bacterial quorum sensing: an unexplored strategy to fight infections in aquaculture. Aquaculture 240(1-4):69-88.

Dennis EU, Uchenna OJ (2016) Use of probiotics as first feed of larval African catfish Clarias gariepinus (Burchell 
1822). Annu Res Rev Biol 9(2):1-9.

Devaraja T, Banerjee S, Yusoff F, Sariff M, Khatoon H (2013) A holistic approach for selection of Bacillus sp. as a bioremediator for shrimp post larvae culture. Turk J Biol 37:92-100.

Dey A, Ghosh K, Hazra N (2016) Evaluation of preference of dry feed, bio-encapsulated and non-bio-encapsulated live feed and survival of the walking catfish, Clarias batrachus (L.) juveniles. Int J Fish Aquat Stud 4(5):545-549.

Dey A, Ghosh K, Hazra N (2017) Improvement of growth and survival of the juvenile walking catfish, Clarias batrachus (L.) (Siluriformes: Clariidae) fed on probiotics encapsulated and ascorbic acid enriched chironomid larvae (Diptera: Chironomidae). Proc Zool Soc.

Dhanasekaran D, Saha S, Thajuddin N, Panneerselvam A (2008) Probiotic effect of Lactobacillus isolates against bacterial pathogens in Clarias orientalis. Facta Universitatis 15(3):97-102.

Dhara K, Saha NC (2013) Controlled breeding of Asian catfish Clarias batrachus using pituitary gland extracts and ovaprim at different temperatures, latency periods and their early development. J Aquac Res Development 4(4):1-9.

Elavarasi K, Ranjini S, Rajagopal T, Rameshkumar G, Ponmanickam P (2013) Bactericidal proteins of skin mucus and skin extracts from fresh water fishes, Clarias batrachus and Tilapia mossambicus. Thai J Pharm Sci 37:194-200.

El-Haroun ER (2007) Improved growth rate and feed utilization in farmed African catfish Clarias gariepinus (Burchell 1822) through a growth promoter Biogen ${ }^{7}$ supplementation. J Fish Aquat Sci 2(5):319-327.

Essa MA, Mabrouk HA, Mohamed RA, Michael FR (2011) Evaluating different additive levels of yeast, Saccharomyces cerevisiae, on the growth and production performances of a hybrid of two populations of Egyptian African catfish, Clarias gariepinus. Aquaculture 320(1-2):137-141.

Falaye A, Emikpe B, Ogundipe E (2016) Influence of Lactobacillus plantarum supplemented diet on growth response, gut morphometry and microbial profile in gut of Clarias gariepinus fingerlings. J Coast Life Med 4(8):597-602.

FAO/OIE/WHO (2006) Antimicrobial use in aquaculture and antimicrobial resistance. Report of a Joint. Expert Consultation on Antimicrobial Use in Aquaculture and Antimicrobial Resistance.

FAO/WHO (2001) Expert consultation report on evaluation of health and nutritional properties of probiotics in food including powder milk with live lactic acid bacteria in health and nutritional properties of probiotics in food including powder milk with live lactic acid bacteria. October

Feliatra F, Elizal E, Lukistyowati I, Melina D, Ramadhani M (2018) Effectiveness of immersion with probiotic in improving the health of Nile Tilapia (Oreochromis niloticus)
Asian J Anim Vet Adv 13:43-51.

Fuller R (1989) Probiotics in man and animals. J Appl Bacteriol 66(5):365-378.

Ganguly A, Mandal A, Khan MA, Dutta TK, Raha S, Das Mohapatra PK (2017) Study of physico-chemical parameters, planktonic diversity and bacterial load of Clarias batrachus Cultivation Pond at Bankura, WB, India. Int res $\mathrm{j}$ biological sci 6(12):23-34.

Ganguly A, Banerjee A, Mandal A, Das Mohapatra PK (2018) Optimization of effective dose of a newly isolated probiotic bacteria for growth and disease resistance of Clarias batrachus (Linn.). Res J Life Sci Bioinform Pharm Chem Sci 4(4):344-354.

Gatesoupe FJ (1994) Lactic acid bacteria increase the resistance of turbot larvae, Scophthalmus maximus, against pathogenic Vibrio. Aquat Living Resour 7:277-282.

Gatesoupe FJ (1999) The use of probiotics in aquaculture. Aquaculture 180(1-2):147-165.

Ghosh K, Sen SK, Ray AK (2004) Growth and survival of rohu Labeo rohita (Hamilton) spawn fed diets fermented with intestinal bacterium, Bacillus circulans. Acta Ichthyol Piscat 34(2):155-165.

Gram L, Melchiorsen J, Spanggaard B, Huber I, Nielsen T (1999) Inhibition of Vibrio anguillarum by Pseudomonas fluorescens strain AH2, a possible probiotic treatment of fish. Appl Environ Microbiol 65(3):969-973.

Hamon E, Horvatovich P, Marchioni E, Aoude-Werner D, Ennahar S (2014) Investigation of potential markers of acid resistance in Lactobacillus plantarum by comparative proteomics. J Appl Microbiol 116:134-144.

Hapsari F (2016) The effect of fermented and non fermented biofloc inoculated with bacterium Bacillus cereus for catfish (Clarias gariepinus) juveniles. AACL Bioflux 9(2):334-339.

Hjelm M, Bergh Ø, Riaza A, Nielsen J, Melchiorsen J, Jensen S, Duncan H, Ahrens P, Birkbeck H, Gram L (2004) Selection and identification of autochthonous potential probiotic bacteria from turbot larvae (Scophthalmus maximus) rearing units. Syst Appl Microbiol 27(3):360-371.

Hoseinifar SH, Dadar M, Ringo E (2017) Modulation of nutrient digestibility and digestive enzyme activities in aquatic animals: The functional feed additives scenario. Aquac Res 48:1-14.

ICAR-CIFA (2016-17) Annual report, Kausalyaganga, Bhubaneswar-751002, Odisha, India

ICAR-CIFA (http://cifa.nic.in/pamphlets).

Ige BA (2013) Probiotics use in intensive fish farming. Afr J Microbiol Res 7(22):2701-2711.

Irianto A, Austin B (2002) Use of probiotics to control furunculosis in rainbow trout, Onchorhynchus mykiss (Walbaum). J Fish Dis 25(6):333-342.

Jahan T, Ayub Ali M, Rahman T (2016) Investigation on the growth performances of selected probiotic supplemented 
tilapia (Oreochromis niloticus) and walking catfish (Clarias batrachus) fingerlings. Fundam Appl Agric 1(2):75-81.

Jayaram KC (1981) The freshwater fishes of India, Pakistan, Bangladesh, Burma, and Sri Lanka. Handbook of Zoological Survey of India, Volume- 2, Calcutta. 475 p.

Kato CD, Kabarozi R, Majalija S, Tamale A, Musisi NL, Sengooba A (2016) Isolation and identification of potential probiotic bacteria on surfaces of Oreochromis niloticus and Clarias gariepinus from around Kampala, Uganda. Afr J Microbiol Res 10(36):1524-1530.

Keysami MA, Mohammadpour M (2013) Effect of Bacillus subtilis on Aeromonas hydrophila infection resistance in juvenile freshwater prawn, Macrobrachium rosenbergii (de Man). Aquac Int 21(3):553-562.

Khedkar GD, Tiknaik AD, Shinde RN, Kalyankar AD, Ron TB, Haymer D (2015) High rates of substitution of the native catfish Clarias batrachus by Clarias gariepinus in India. Mitochondrial DNA.

Kim DH, Austin B (2006) Innate immune responses in rainbow trout (Oncorhynchus mykiss, Walbaum) induced by probiotics. Fish Shellfish Immunol 21(5):513-524.

Kim DH, Brunt J, Austin B (2007) Microbial diversity of intestinal contents and mucus in rainbow trout (Oncorhynchus mykiss). J Appl Microbiol 102:1654-1664.

Krasowska A, Sigler K (2014) How microorganisms use hydrophobicity and what does this mean for human needs? Front Cell Infect Microbiol 4:1-7.

Lara-Flores M, Olvera-Novoa MA, Guzman-Mendez BE, Lopez-Madrid W (2003) Use of the bacteria Streptococcus faecium and Lactobacillus acidophilus, and the yeast Saccharomyces cerevisiae as growth promoters in Nile tilapia (Oreochromis niloticus). Aquaculture 216(1-4):193-201.

Majed R, Faille C, Kallassy M, Gohar M (2016) Bacillus cereus biofilms - same, only different. Front Microbiol 7:1054.

Mohanty B, Mahanty A, Ganguly S, Sankar TV, Chakraborty K, Rangasamy A, Paul B, Sarma D, Mathew S, Asha KK, Behera BK, Aftabuddin M, Debnath D, Vijayagopal P, Sridhar N, Akhtar MS, Sahi N, Mitra T, Banerjee S, Paria P, Das D, Das P, Vijayan KK, Laxmanan PT, Sharma AP (2014) Amino acid compositions of 27 food fishes and their importance in clinical nutrition. J Amino Acids.

Naylor RL, Goldburg RJ, Primavera JH, Kautsky N, Beveridge MCM, Clay J, Folke C, Lubchenco J, Mooney H, Troell M (2000) Effect of aquaculture on world fish supplies. Nature 405:1017-1024.

Newaj-Fyzul A, Adesiyun AA, Mutani A, Ramsubhag A, Brunt J, Austin B (2007) Bacillus subtilis AB1 controls Aeromonas infection in rainbow trout (Oncorhynchus mykiss, Walbaum). J Appl Microbiol 103(5):1699-1706.

$\mathrm{Ng} \mathrm{HH}$, Kottelat M (2008) The identity of Clarias batrachus (Linnaeus, 1758), with the designation of a neotype (Teleostei: Clariidae). Zool J Linn Soc 153:725-732.

Nikoskelainen S, Ouwehand AC, Bylund G, Salminen S,
Lilius EM (2003) Immune enhancement in rainbow trout (Oncorhynchus mykiss) by potential probiotic bacteria (Lactobacillus rhamnosus). Fish Shellfish Immunol 15(5):443-452.

Novita H, Rusmana I, Yuhana M, Pasaribu FH (2015) Potential of Bacillus sp., as a producer of AHL lactonase and its application as a probiotic for the prevention of Mas in catfish (Clarias gariepinus). J Fish Aquat Sci 10(6):464-476.

Nwanna LC, Tope-Jegede H (2016) Effects of dietary Lactobacillus plantarum on the growth, carcass quality, and immune response of African catfish (Clarias gariepinus) challenged with Salmonella typhi. J Appl Aquacult 29(1):62-80.

Ogunshe AAO, Olabode OP (2009) Antimicrobial potentials of indigenous Lactobacillus strains on gram-negative indicator bacterial species from Clarias gariepinus (Burchell.) microbial inhibition of fish-borne pathogens. Afr J Microbiol Res 3(12):870-876.

Olayinka AS, Afolabi OO (2013) Evaluation of the effects of Lactobacillus acidophilus on the haematological parameters of Clarias gariepinus. Int J Res Fish Aquac 3(2):38-41.

Omenwa VC, Mbakwem-Aniebo C, Ibiene AA (2015) Effects of selected probiotics on the growth and survival of fry - fingerlings of Clarias gariepinus. IOSR J Pharm Biol Sci 10(5):89-93.

Paiva-Maia ED, Alves-Modesto G, Otavio-Brito L, Olivera A, Vasconcelos-Gesteira TC (2013) Effect of a commercial probiotic on bacterial and phytoplankton concentration in intensive shrimp farming (Litopenaeus vannamei) recirculation systems. Lat Am J Aquat Res 41(1):126-137.

Panigrahi A, Kiron V, Puangkaew J, Kobayashi T, Satoh S, Sugita H (2005) The viability of probiotic bacteria as a factor influencing the immune response in rainbow trout (Oncorhynchus mykiss). Aquaculture 243(1-4):241-254.

Papadimitriou K, Zoumpopoulou G, Foligné B, Alexandraki V, Kazou M, Pot B, Tsakalidou E (2015) Discovering probiotic microorganisms: in vitro, in vivo, genetic and omics approaches. Front Microbiol 6:1-28.

Pathak SP, Gopal K (2005) Occurrence of antibiotic and metal resistance in bacteria from organs of river fish. Environ Res 98(1):100-103.

Putra I, Rusliadi R, Fauzi M, Tang UM, Muchlisin ZA (2017) Growth performance and feed utilization of African catfish Clarias gariepinus fed a commercial diet and reared in the biofloc system enhanced with probiotic. F1000Research 6:1545.

Radhakrishnan KV, Lan ZJ, Zhao J, Qing N, Huang XL (2011) Invasion of the African sharp-tooth catfish Clarias gariepinus (Burchell, 1822) in South China. Biol Invasions 13:1723-1727.

Ran C, Carrias A, Williams MA, Capps N, Dan BCT, Newton JC, Kloepper JW, Ooi EL, Browdy CL, Terhune JS, Liles MR (2012) Identification of Bacillus strains for biological 
control of catfish pathogens. PLoS ONE 7(9):e45793.

Reneshwary C, Rajalakshmi M, Marimuthu K, Xavier R (2011) Dietary administration of Bacillus thuringiensis on the cellular innate immune response of African catfish (Clarias gariepinus) against Aeromonas hydrophila. Eur Rev Med Pharmacol Sci 15(1):53-60.

Rengpipat S, Phianphak W, Piyatiratitivorakul S, Menasveta P (1998) Effects of a probiotic bacterium on black tiger shrimp Penaeus monodon survival and growth. Aquaculture 167(3-4):301-313.

Ringo E, Salinas I, Olsen RE, Nyhaug A, Myklebust R, Mayhew TM (2007) Histological changes in intestine of Atlantic salmon (Salmo salar L.) following in vitro exposure to pathogenic and probiotic bacterial strains. Cell Tissue Res 328:109-116.

Robertson PAW, O’Dowd C, Burrells C, Williams P, Austin B (2000) Use of Carnobacterium sp. as a probiotics for Atlantic salmon (Salmo salar L.) and rainbow trout (Oncorhynchus mykiss, Walbaum). Aquaculture 185(34):235-243.

Sahu MK, Swarnakumar NS, Sivakumar K, Thangaradjou T, Kannan L (2008) Probiotics in aquaculture: importance and future perspectives. Indian J Microbiol 48(3):299308.

Salinas I, Abelli L, Bertoni F, Picchietti S, Roque A, Furones D, Cuesta A, Meseguer J, Esteban MA (2008) Monospecies and multispecies probiotic formulations produce different systemic and local immunostimulatory effects in the gilthead seabream (Sparus aurata L.). Fish Shellfish Immunol 25(1-2):114-123.

Sun YZ, Yang HL, Ma RL, Lin WY (2010) Probiotic applications of two dominant gut Bacillus strains with antagonistic activity improved the growth performance and immune responses of grouper Epinephelus coioides. Fish Shellfish Immunol 29(5):803-809.
Talwar PK, Jhingran AG (1991) Inland fishes of India and adjacent countries. Volume- 1. Oxford and IBH Publishing Co. Pvt. Ltd., New Delhi, India. 541.

Tovar D, Zambonino J, Cahu C, Gatesoupe FJ, VazquezJuarez R, Lesel R (2002) Effect of live yeast incorporation in compound diet on digestive enzyme activity in sea bass (Dicentrarchus labrax) larvae. Aquaculture 204(1-2):113-123.

Tripathy PP, Suar M, Das JK, Saini MR (2014) Probiotic and functional characteristics of an indigenous Lactobacillus species isolated from traditional fermented product (Dahi-Chenna) of rural Odisha. Int J Curr Microbiol App Sci 3(11):82-95.

Vlamakis H, Chai Y, Beauregard P, Losick R, Kolter R (2013) Sticking together: building a biofilm the Bacillus subtilis way. Nat Rev Microbiol 11:157-168.

Wang YB, Li JR, Lin J (2008) Probiotics in aquaculture: Challenges and outlook. Aquaculture 281:1-4.

Wang YB, Xu ZR, Xia MS (2005) The effectiveness of commercial probiotics in northern white shrimp (Penaeus vannamei) ponds. Fish Sci 71:1036-1041.

Yakubu AF, Olaji ED, Adams TE (2016) Effect of probiotic (Biogut) on the growth and survival of Clarias gariepinus Burchell, 1822 fry in glass aquaria tanks. Eur J Appl Sci 8(6):326-329.

Zhao X, Kuipers OP (2016) Identification and classification of known and putative antimicrobial compounds produced by a wide variety of Bacillales species. BMC Genomics 17:882. 
